\title{
Risk factors for childhood asthma deaths from the UK Eastern Region Confidential Enquiry 2001-2006
}

\author{
Katherine Anagnostoua, Brian Harrison ${ }^{b}$, Richard Ilesc, *Shuaib Nasser \\ a Department of Allergy, Cambridge University Hospitals NHS Trust, Cambridge, UK \\ b School of Medicine, Health Policy and Practice, University of East Anglia, Norwich, UK \\ Department of Respiratory Paediatrics, Cambridge University Hospitals NHS Trust, Cambridge, UK
}

Received 9th May 2011; resubmitted 26th August 2011; revised 9th September 2011; accepted 13th September 2011; online 4th January 2012

\begin{abstract}
Background: Confidential enquiries into asthma deaths can identify inadequacies in medical management and factors which contribute to patients' death.

Aims: To identify risk factors for paediatric asthma deaths over a 6-year period.

Methods: Observational case-series study of paediatric asthma deaths between 2001-2006 in the UK Eastern Region. Hospital, primary care and post-mortem data were obtained for every child ( $\leq 17 \mathrm{yrs}$ ) with asthma recorded on the death certificate, and a detailed questionnaire was completed. Information was obtained on asthma severity, medications, hospital admissions, GP and hospital follow-up, adherence, psychosocial / behavioural factors, allergies, details of the terminal attack and precipitating factors.

Results: 20 children (10 male; 8-17yrs; median: 11.5yrs) died of asthma between 2001-2006. 9/20 had mild to moderate asthma (BTS/ SIGN criteria), 10/20 had severe asthma and 1 child was not known to have asthma. 13/20 were clinically atopic. Only 3 had undergone allergy assessment. 10/20 died between June and August. 12/20 children had adverse psychosocial and behavioural factors. 7/20 children were on non-combination long-acting $\beta_{2}$-agonist (LABA) treatment without inhaled corticosteroids (ICS).

Conclusions: Almost half the deaths occurred in children with mild/moderate asthma. We recommend that allergic factors and seasonal allergy should be identified early, non-combination LABAs avoided, and speculate that overuse of short-acting $\beta_{2}$-agonists (SABAs) may indicate non-adherence with ICS. Asthma deaths in children can be avoided if risk factors are identified early.

(C) 2012 Primary Care Respiratory Society UK. All rights reserved.

K Anagnostou et al. Prim Care Respir J 2012; 21(1): 71-77

http://dx.doi.org/10.4104/pcrj.2011.00097
\end{abstract}

Keywords asthma, deaths, allergy, inhaled corticosteroids, LABAs, SABAs, seasonal, adherence, behavioural, psychosocial, children, paediatric, risk factors

\section{See linked editorial by Stephenson \& Shields on pg 13}

\section{Introduction}

In the UK, asthma mortality peaked in the mid 1960s and again in the late 1970s and early 1980s. In response to these worrying statistics, a Confidential Enquiry into asthma deaths in children and adults was started in Eastern England in 1988. Initially, only deaths in the Norwich Health District were investigated, but in 1992 the Enquiry was extended to East Anglia (Norfolk, Suffolk and Cambridgeshire). In 2001 the Enquiry was further extended to include the whole of the Eastern Region of the UK.

Data from the Office of National Statistics (ONS) show that rates of childhood mortality from asthma have been on the decline since the epidemic of asthma deaths in the mid-1960s, when they reached 10 per million among children aged under 5 years and 14 per million among 5-14 year-olds. Between 1990 and 2000, asthma-related deaths among children aged under 5 years and those aged 5-14 years remained uncommon at around 2 per million each year. ${ }^{2}$

Previous UK Eastern Region Confidential Enquiries into asthma deaths in children and adults < 65 years old have identified behavioural and psychosocial factors as well as seasonal allergic factors as contributing to the patient's death. In two-thirds of asthma deaths medical management failed to

\footnotetext{
*Corresponding author: Dr Shuaib Nasser, Department of Allergy, Cambrdige University Hospitals NHS Trust, Hills Rd, Cambridge, CB2 0QQ, UK. Tel: +44 (0)1223 586977 E-mail: shuaib.nasser@addenbrookes.nhs.uk
} 
comply with national guidelines. ${ }^{3 \cdot 5} \mathrm{~A}$ number of previous studies from different parts of the world have also reported on risk factors contributing to asthma deaths. ${ }^{6-13}$

The aim of this observational study was to identify risk factors contributing to asthma deaths in children during a 6-year study period (2001-2006). The Eastern Region population is approximately 5.5 million, $22 \%$ of whom $(1,276,000)$ are children below the age of 18 years. ${ }^{14}$ This is the first report on asthma deaths in children in the Eastern Region of the UK.

\section{Methods}

The methods used during the 2001-2003 period have been reported previously, ${ }^{5}$ and the same methodology was used for the remainder of this six-year study (2001-2006). In brief, the Chair of the Confidential Enquiry requested patient details from the ONS relating to deaths in patients $<18$ years old in the Eastern Region of the UK in the previous 12 months (each year for the six years of the study) with asthma recorded in the first part of the death certificate. The Eastern Region of the UK consists of the counties of Norfolk, Suffolk, Cambridgeshire, Bedfordshire, Essex and Hertfordshire, and the Unitary Authorities of Peterborough, Luton and Southend-On-Sea. The Enquiry excluded the area within the M25 London orbital motorway.

Each patient's details were distributed to two members of the Confidential Enquiry Working Group - a respiratory physician/paediatrician in the District General Hospital (DGH) nearest to where the patient lived, and a general practitioner (GP). The respiratory physician/paediatrician obtained the local hospital notes and in conjunction with the child's paediatrician completed a detailed proforma related to the patient's asthma and overall asthma care. The proforma included information on asthma severity, medication, hospital admissions, GP and/or hospital follow-up, compliance with medication, psychosocial and behavioural factors, allergies, details of the terminal attack and suspected precipitating factors.

A GP from the Working Group obtained the general practice records and made a detailed review of the patient's notes. The results of all available post-mortem examinations were also reviewed. Patients were excluded from the enquiry at this stage if the hospital and/or general practice records or the postmortem report revealed that the main cause of death was not asthma. The GP member then contacted the deceased's GP before completing a proforma detailing all aspects of asthma management, including the number of prescriptions issued for each asthma medication, how often appointments were missed, whether the patient attended for asthma review regularly, whether or not a management plan had been issued, and how often peak flow measurements had been recorded.

Asthma severity was classified by the working group members using the British Thoracic Society (BTS)/Scottish Intercollegiate Guideline Network (SIGN) stepwise guidelines for asthma treatment: mild (BTS steps 1-2), moderate (BTS step 3) and severe (BTS steps 4-5). ${ }^{15}$ Admissions to hospital or visits to the Accident and Emergency department for the previous 12 months were also taken into account when assessing severity (i.e. severe asthma = BTS steps 4-5 or at least two hospital admissions in the previous year). Allergy testing for asthma is not routinely carried out in the UK and only a limited number of patients had results of skin testing recorded in either the primary care or secondary care notes. Therefore only limited data were available on atopy, known allergies and possible anaphylactic precipitating factors.

Socioeconomic data were derived for each patient based on their home address/permanent place of residence. A Multiple Deprivation Score Index (MDS index) was calculated from seven weighted domain scores using the following: Income (22.5\%), Employment (22.5\%), Health Deprivation and Disability (13.5\%), Education, Skills and Training (13.5\%), Barriers to Housing and Services (9.3\%), Crime (9.3\%) and Living Environment (9.3\%). An MDS index close to 1 suggests a good socioeconomic status. ${ }^{16}$

A Summary Form - incorporating all the relevant information obtained from the records, post-mortem examination and interview with the deceased's GP - was then completed following discussion with members of the Working Group. National guidelines on asthma management ${ }^{15}$ were used to define standards and to make judgements on the appropriateness of medical care received by the patient.

Ethics approval was not required for this study.

\section{Results}

Between 2001-2006, 20 children (10 males) died from asthma in Eastern England. Ages ranged between 8-17yrs (median age 11.5yrs). Patient characteristics are shown in Table 1.

\section{Asthma severity}

Using BTS/SIGN guidelines to assess severity, 9/20 children had mild to moderate asthma (BTS steps 1-3). Of these, three children had previous hospital admissions (although none in the previous 12 months). 10/20 children were graded with severe asthma (BTS steps 4-5) and of these nine had admissions to hospital in the previous year (one admitted to the intensive care unit (ICU)). One child had no prior recorded history of asthma before death, and died suddenly with asthma recorded as the cause of death which was confirmed by post-mortem examination. (see Figure 1).

\section{Health care factors}

Five out of the 10 children with severe asthma were managed solely in primary care and had never been seen in hospital by a respiratory specialist. One of these children had been referred to hospital two months prior to death but had not been seen by the time of death. None of the five had a written asthma management plan. In total, only $6 / 20$ children had a record of a written asthma management plan. Only 5/20 children had a peak flow measurement recorded (either in primary or secondary care) within a year of death. Spirometry was recorded in only 
Table 1. Characteristics of the 20 paediatric patients who died from asthma, Eastern Region, 2001-2006.

\begin{tabular}{|c|c|c|c|c|c|c|c|c|c|c|c|c|}
\hline Age & Sex & $\begin{array}{l}\text { Severity/ } \\
\text { BTS step } \\
\text { guidelines }\end{array}$ & ICS & $\begin{array}{l}\text { Non } \\
\text { combination } \\
\text { LABAs }\end{array}$ & $\begin{array}{l}\text { Oral } \\
\text { prednisolone }\end{array}$ & $\begin{array}{l}\text { Previous } \\
\text { admissions }\end{array}$ & Atopy & Adherence & Social & $\begin{array}{l}\text { Asthma } \\
\text { plan }\end{array}$ & PF & Anaphylaxis/SD \\
\hline 11 & $\mathrm{~F}$ & Mild-2 & Yes & No & No & No & NK & Poor & - & No & No & SD \\
\hline 15 & M & Severe-4 & Yes & Yes & No & Yes & $\begin{array}{l}\text { Dog } \\
\text { allergy }\end{array}$ & Good & $\begin{array}{l}\text { Domestic } \\
\text { problems }\end{array}$ & No & No & $\begin{array}{l}\text { Suspected anaphylaxis } \\
\text { (dog walk prior to death) }\end{array}$ \\
\hline 10 & M & Severe-5 & Yes & Yes & Yes & Yes & NK & Poor & - & No & No & $\begin{array}{l}\text { Gradual deterioration } \\
\text { over } 24 \mathrm{~h}\end{array}$ \\
\hline 15 & $M$ & Mild-1 & No & No & No & No & NK & Good & - & No & No & SD \\
\hline 8 & $\bar{F}$ & Severe-5 & Yes & Yes & Yes & Yes & $\begin{array}{l}\text { Eczema } \\
\text { dog allergy }\end{array}$ & Good & - & No & Yes & $\begin{array}{l}\text { Gradual deterioration } \\
\text { over } 24 \mathrm{~h}\end{array}$ \\
\hline 16 & M & Severe-4 & Yes & No & Yes & Yes & $\begin{array}{l}\text { Allergic } \\
\text { rhinitis aspirin }\end{array}$ & Poor & $\begin{array}{l}\text { Family } \\
\text { discordance }\end{array}$ & Yes & No & $\begin{array}{l}\text { Suspected anaphylaxis } \\
\text { New pet (rat) }\end{array}$ \\
\hline 12 & $\mathrm{~F}$ & $\begin{array}{l}\text { Not known } \\
\text { asthma }\end{array}$ & No & No & No & No & NK & - & - & - & - & SD \\
\hline 11 & M & Severe-3 & Yes & No & No & Yes & $\begin{array}{l}\text { +ve SPT } \\
\text { to HDM }\end{array}$ & Good & $\begin{array}{l}\text { Family } \\
\text { discordance }\end{array}$ & No & Yes & SD \\
\hline 10 & M & Severe-3 & Yes & No & Yes & Yes & $\begin{array}{l}\text { Eczema } \\
\text { Nut allergy }\end{array}$ & Good & $\begin{array}{l}\text { Unable to } \\
\text { recognise } \\
\text { severity }\end{array}$ & Yes & Yes & $\begin{array}{l}\text { Suspected anaphylaxis } \\
\text { (nut) }\end{array}$ \\
\hline 9 & $\mathrm{~F}$ & $\begin{array}{l}\text { Mild/ } \\
\text { moderate-3 }\end{array}$ & No & Yes & No & No & $\begin{array}{l}\text { Eczema } \\
\text { Animal allergy }\end{array}$ & Poor & $?$ & $?$ & $?$ & $\begin{array}{l}\text { Suspected anaphylaxis } \\
\text { (guinea pig exposure) }\end{array}$ \\
\hline 16 & $\mathrm{~F}$ & Moderate-3 & No & Yes & No & No & NK & Poor & - & $?$ & $?$ & SD \\
\hline 12 & $\mathrm{~F}$ & Severe-2 & Yes & No & No & No & NK & $?$ & - & No & No & SD \\
\hline 8 & M & Severe-3 & Yes & Yes & No & Yes & Dog allergy & $?$ & - & $?$ & $?$ & $\begin{array}{l}\text { Suspected anaphylaxis } \\
\text { Dog exposure }\end{array}$ \\
\hline 15 & $\mathrm{~F}$ & Moderate-3 & Yes & Yes & No & No & Eczema & Poor & $\begin{array}{l}\text { Domestic } \\
\text { violence }\end{array}$ & $?$ & $?$ & SD \\
\hline 15 & $\mathrm{~F}$ & Moderate-3 & Yes & No & Yes & Yes & $\begin{array}{l}\text { Seasonal asthma } \\
\text { Hay fever }\end{array}$ & Good & - & Yes & $?$ & $\begin{array}{l}\text { SD } \\
\text { Thunderstorm }\end{array}$ \\
\hline 17 & M & Moderate-3 & Yes & Yes & No & Yes & $\begin{array}{l}\text { Seasonal } \\
\text { asthma }\end{array}$ & Poor & Denial & No & $?$ & $\begin{array}{l}\text { Unwell for } 3 \text { days } \\
\text { Thunderstorm }\end{array}$ \\
\hline 10 & $\mathrm{~F}$ & Moderate-3 & Yes & No & No & No & $\begin{array}{l}\text { Seasonal asthma } \\
\text { Hay fever } \\
\text { Eczema }\end{array}$ & Good & - & Yes & Yes & $\begin{array}{l}\text { SD } \\
\text { Thunderstorm }\end{array}$ \\
\hline 9 & M & Severe-4 & Yes & No & Yes & Yes & $\begin{array}{l}\text { Severe eczema } \\
\text { Milk + Peanut } \\
\text { allergy }\end{array}$ & Good & - & Yes & $?$ & SD \\
\hline 9 & M & Moderate-3 & Yes & No & No & Yes & Eczema & Poor & Denial & Yes & Yes & SD \\
\hline 10 & $\mathrm{~F}$ & Severe-3 & Yes & No & No & Yes & Eczema & Poor & Neglect & No & No & SD \\
\hline
\end{tabular}

$\mathrm{ICH}=$ inhaled corticosteroids; $\mathrm{PF}=$ peak flow; $\mathrm{LABAs}=$ long acting $\beta$-agonists; $\mathrm{NK}=$ not known; $\mathrm{SD}=$ sudden death; $\mathrm{SPT}=$ skin prick test; HDM= house dust mite

?= information not available; +ve=positive

7/20 children (6/7 suffered from severe asthma). In 6/20 GP practices there was a respiratory nurse specialising in asthma (each specialist nurse had attended a recognised training course for asthma within the last two years).

For $8 / 20$ children, follow-up for their asthma was considered inadequate. Only 7/20 children were under regular review in an asthma clinic (either hospital or primary care) during the year preceding their death.

One child with severe asthma was seen 16 hours prior to death by a GP and was misdiagnosed as croup: no treatment had been given. The child was seen again 4 hours prior to death by a different GP who diagnosed an asthma attack, gave nebulisers and oral prednisolone but did not refer the child to hospital.

Four children had co-existing medical conditions (ADHD, epilepsy, neurofibromatosis disease type 1 , and autism with learning difficulties).

\section{Drug treatment and adherence}

Of the patient cohort, 9/20 children were poorly compliant with prescribed medication and 6/20 children had poorly controlled asthma despite taking their recommended treatment (which was 


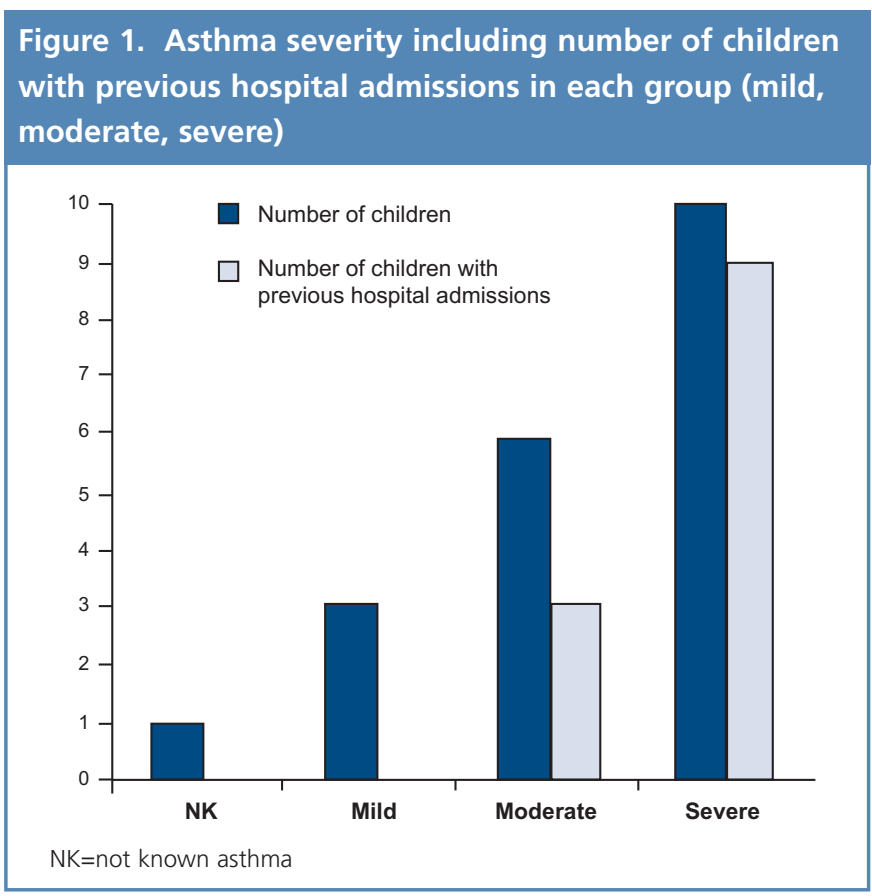

\begin{tabular}{|c|c|}
\hline $\begin{array}{l}\text { No record of peak flow monitoring over last year } \\
\text { prior to death }\end{array}$ & $15(75 \%)$ \\
\hline No record of written asthma management plan & $14(70 \%)$ \\
\hline Inadequate follow up & $8(40 \%)$ \\
\hline Delayed or no referral to specialist & $5(25 \%)$ \\
\hline Follow up in hospital asthma clinic at time of death & $7(35 \%)$ \\
\hline $\begin{array}{l}\text { Inadequate doses of inhaled corticosteroids or } \\
\text { delayed doses of oral prednisolone }\end{array}$ & $8(40 \%)$ \\
\hline $\begin{array}{l}\text { Number of patients on non-combination LABAs } \\
\text { without prescribed ICS }\end{array}$ & $2(10 \%)$ \\
\hline $\begin{array}{l}\text { Number of patients prescribed non-combination } \\
\text { LABAs and ICS but non-compliant with ICS }\end{array}$ & $4(20 \%)$ \\
\hline
\end{tabular}

therefore considered to be inadequate). Seven children had been prescribed non-combination LABAs and of these six were not taking ICS - two children had not been prescribed ICS and four children were not taking their prescribed ICS. 8/20 children were on inadequate doses of ICS or were not commenced on oral prednisolone in time (see Table 2).

Adherence to treatment was defined as the extent to which patient behaviour matched the health professional's recommendation. Poor adherence was defined as taking less than $50 \%$ of the recommended inhaled medication or omission of all inhaled medication for one week or longer over the previous six months.

\section{Adverse behavioural/psychosocial factors}

Overall, 12/20 children had psychosocial or behavioural factors which may have contributed to their death. 6/12 children came
Figure 2. Number of asthma deaths in different months; there is a clear peak in the months of June/July/August which most likely represents seasonal asthma

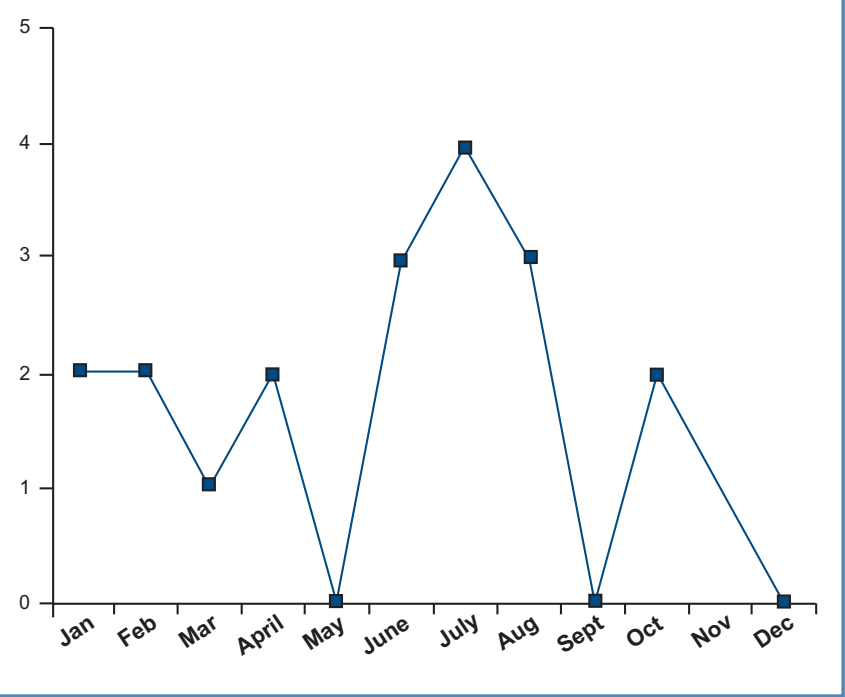

from dysfunctional families or families with serious domestic problems. 2/12 children were in denial about their asthma, and therefore did not recognise the severity of their disease and the need for regular treatment. 5/12 children displayed poor adherence with their medication and attending appointments.

Two of the children were smokers. No information on parental smoking was available.

Four out of the 20 children were taken to hospital in the parent's car and died on route while stuck in traffic. In two cases an ambulance was refused by the parents who preferred to use their own transport.

Analysis of the socioeconomic data of our patient cohort revealed a distribution that was similar to the socioeconomic profile of the Eastern region with less than a third of patients belonging to the 'deprived' group.

\section{Allergic and seasonal factors}

At least 13/20 children were likely to be atopic with a clinical picture consistent with atopic disease, but only three had had a formal allergy assessment in an allergy clinic to confirm this. There was insufficient information on atopic status on six out of the remaining seven children - the seventh child was not known to have asthma and no data were available on atopy either.

In 4/20 children, animal exposure was a likely allergic trigger before death (a dog in two cases, guinea pig in one, and a newly-acquired rat in one). One child who was known to be allergic to nuts had documented exposure to nuts shortly before the fatal attack and another child had aspirin sensitivity but there is no evidence that NSAID ingestion contributed to his death. There were no data available regarding allergies to medication on any other patients.

Ten of the 20 children died between June and August. Two had mild asthma and both suffered sudden death, implying an 
acute allergic trigger (see Figure 2). Three deaths during this period occurred during a thunderstorm. In a further five children there was evidence of allergen exposure shortly prior to death in four cases exposure to an animal or pet, and in one case exposure to nuts. None of these children had a post-mortem serum measurement for tryptase.

\section{Discussion}

\section{Main findings and interpretation in relation to previously published work}

Severity of asthma is an important risk factor for paediatric asthma deaths: half of the 20 children who died in the Eastern Region of the UK between 2001-2006 were considered to have severe asthma. Five of these 10 were on BTS/SIGN treatment steps 4 or 5 and the rest were under-treated but had had at least two hospital admissions within the previous 12 months. A number of risk factors were identified in this severe group including use of non-combination LABA inhalers, inadequate health care, under-treatment with ICS, delayed referral to a specialist, and under-estimation of disease severity by close family members and in some cases medical staff. Psychosocial factors are common in this group, but poor compliance was less common than in those considered to have mild/moderate asthma. Furthermore, 7/10 children with severe asthma were atopic but only two of them had undergone formal allergy assessment.

It is of interest that almost half the deaths occurred in children with mild to moderate asthma. Our results are in accord with the Victoria study in which the majority of deaths could not be classified as "high risk", with 33\% judged to have a history of trivial or mild asthma and $32 \%$ no previous hospital admissions for asthma. ${ }^{17}$ In our study, nine children had been prescribed treatment from BTS/SIGN steps 1-3 and were therefore considered to have mild to moderate asthma. This group displayed a different cluster of risk factors. Six were clinically atopic but the atopic status of the other three could not be determined. Other risk factors included seasonal asthma (3/9), poor compliance with medication (6/9), and use of non-combination LABA inhalers (4/9). Seasonal asthma often remains unrecognised in patients considered to have 'mild' asthma, who can suddenly become unwell when they receive a large allergen load during the pollen or fungal spore seasons. Other allergic triggers such as pets and foods - especially nuts - can cause severe or even fatal asthma in patients with poorly controlled disease or bronchial hyperreactivity due to seasonal allergen exposure."

Peak flow measurements were poorly recorded in the primary care notes in our patient group. It is important that objective measures of lung function are recorded routinely in children with asthma at each follow-up appointment. These measures provide a basis for comparison during times of illness and are essential for evaluating the severity of disease.

Spirometry was recorded in only a minority of cases, and an assessment of asthma severity based on symptoms and treatment was often inaccurate. Baseline spirometry is known to give an accurate "snapshot" of asthma severity, and the FEV 1 derived from spirometry is linearly related to the severity of airways obstruction. ${ }^{18}$ Ramsey et al. also suggest that $\mathrm{FEV}_{1} / \mathrm{FVC}$ is a useful indicator of asthma severity in children. ${ }^{19}$ Spirometry is reproducible, with most children able to perform acceptable spirometry with $50 \%$ success by the age of 6 and with $85 \%$ success at age 10 . Methods and results are standardised and spirometers widely available. . $^{19,20}$

Overall, only 6/20 children had any record of a written asthma management plan and this may have contributed to poor compliance or confusion with treatment leading up to death. A recent review has shown that there is strong paediatric evidence that the addition of a written action plan significantly improves outcomes. ${ }^{21,22}$ During acute exacerbations a written record of the best treatment options is likely to be particularly useful - and therefore all children should have a detailed management plan which is updated on a regular basis.

Seven of the asthma deaths occurred in children prescribed non-combination LABA inhalers, and none of these had a written asthma management plan. In at least half of these cases there was evidence of a lack of compliance with ICS treatment. In asthma, the overuse of $\beta_{2}$-agonists combined with under-use of anti-inflammatory medications is associated with increased mortality. ${ }^{23}$ Recent studies have suggested that LABAs may increase severe and life-threatening asthma exacerbations as well as asthma-related deaths, especially when used without regular ICS. 24,25 Therefore, non-combination LABA inhalers should not be used in asthma. In addition it is essential for primary care to have a system that flags up patients who use excessive amounts of SABAs.

A significant proportion of the children had psychosocial or behavioural factors which may have affected compliance with medication and attendance at appointments. This finding is in line with other studies investigating risk factors for fatal asthma: domestic problems, family discordance, neglect, smoking, denial, non compliance with medication, failure to attend appointments and delay in seeking medical help, have all been shown to contribute to adverse outcomes. ${ }^{6-13}$ These factors must be taken into account when children are seen and assessed for asthma, and a special effort should be made to improve compliance.

Two of our subjects were known smokers. There is strong evidence that cigarette smoking in asthma is associated with poor symptom control, and smokers have more severe symptoms and are more likely to be admitted to hospital compared with non-smokers with asthma. ${ }^{26,27}$ Active smokers also present impaired short-term therapeutic responses to corticosteroids: the underlying mechanism remains unresolved but could result from alterations in airway inflammatory cell phenotypes, changes in the glucocorticoid receptor alpha to beta ratio, and increased activation of pro-inflammatory transcription factors or reduced histone deacetylase activity. ${ }^{2,29}$ 
In four out of the 20 deaths, children were taken to hospital in the parent's car and died on route whilst stuck in traffic. It is possible that these deaths could have been averted by the rapid arrival of a paramedic in an ambulance where oxygen-driven nebulisers and adrenaline are readily available. Previous studies have suggested that delay in receiving medical help affects outcome. . $^{8,12}$

In the UK, children with asthma do not undergo routine allergy testing and atopy remains unidentified. Therefore, amongst these 20 children there was a lack of recorded information on allergic status. However, we found that asthma deaths peaked between the months of June and August. Researchers in Denmark who reviewed 108 asthma deaths in children aged 1-19 years old in the years 1973-1994 also noticed a similar peak in mortality in the summer months in patients who were more likely to be atopic, had fewer asthma symptoms, and who were not under regular review for their asthma. ${ }^{9}$ Of the 10 seasonal deaths, at least half the children were clinically atopic but no information on atopy was available for the rest. Only two of the 10 had a record of an asthma management plan. None of them was under hospital review for their asthma, although 6/10 were under GP follow-up once a year but not necessarily prior to the onset of the pollen season. Five of the 10 seasonal deaths occurred in patients on LABAs with four of them not compliant with regular medication. Children with seasonal asthma are at high risk as they are usually asymptomatic out of season, remain unprotected by ICS treatment, and increase their use of SABAs or LABAs when they suddenly receive a large allergen load.

In four children there was documented animal exposure prior to death. One child was playing with a guinea pig belonging to a friend and another child was exposed to a newly acquired pet rat. Two other children were in contact with dogs at the time of death. In all the above cases exposure to the pet may have been the allergic trigger. None of these children was ever assessed formally for pet allergy and no skin testing results were available for any of them. In one case there was documented exposure to nuts prior to death (the patient was known to be nut allergic). Acute severe asthma due to anaphylaxis as a cause of sudden death may be underestimated. A group of researchers in Sweden who evaluated 37 children and young adults who died of asthma noted that a significant proportion of deaths were probably caused by food allergy and that for $8 / 37$ of the subjects death was associated with exposure to pet dander. ${ }^{11}$ In a recent US study, children admitted to a paediatric ICU for asthma exacerbation were significantly more likely to report food allergy compared with children admitted to a regular paediatric ward or seen in ambulatory care. The researchers concluded that self-reported food allergy is an independent risk factor for potentially fatal childhood asthma. ${ }^{30}$ Therefore, not only is poorly controlled asthma a risk factor for deaths due to food allergy, but food allergy in an asthmatic child is a marker for a potentially fatal outcome.

In three cases, asthma deaths occurred during a thunderstorm. All three children suffered from seasonal asthma and two of them also suffered from hay fever. Thunderstormrelated asthma is increasingly recognised in sensitised, atopic individuals before a sudden, large allergen exposure particularly consisting of fungal spores such as Alternaria alternata. Thunderstorm-related asthma usually occurs at a time and location during an allergen season in which large numbers of patients with asthma are outdoors. ${ }^{31}$

\section{Strengths and limitations of this study}

This is a retrospective, uncontrolled, observational study and therefore has inherent limitations. The amount of information available for each patient is limited by the quality of recordkeeping in both primary and secondary care. Patient records in GP practices and hospitals are either electronic or handwritten, and the clinical details are variable. Self-reported data from GPs (when missing from the patient's chart) may have introduced some bias and could not be substantiated because relatives were not interviewed. The determination of social dysfunction was not standardised, allowing for the possibility of incorrect classification. The use of ICS prescribing data from GP records may have resulted in under-reporting of non-adherence.

However, in most cases, a combination of primary and secondary care records, as well as post-mortem results, provided sufficient insight to enable conclusions to be drawn - with a remarkable degree of consistency - into the circumstances surrounding these asthma deaths. There can be an element of subjectivity when clinical data are interpreted, but this was minimised by detailed discussion and the need for consensus amongst the large number of professionals on the Working Group; this is a strength of this study.

Implications for future research, policy and practice

Children with severe asthma are at high risk of asthma exacerbations and should have shared care in both primary and specialist secondary care. There is also a need for prompt referral to hospital for children who have frequent asthma exacerbations and specialist follow-up for children after hospital admission. Recognising the symptoms and seeking prompt medical help during an exacerbation can affect outcome.

As part of their regular management and follow-up, all children with asthma should have received training in the use of a peak flow meter (once they are of an age where their peak flow technique is reliable and reproducible) and use of their inhalers, and should have received an individual asthma management plan. Both the child and the family should be educated on how to recognise acute exacerbations and respond appropriately.

Our results suggest that determination of atopic status and specific allergic sensitisation is an essential part of the management of all children with a diagnosis of asthma. We recommend that children with asthma undergo formal allergy assessment to identify allergic triggers and be provided with a written management plan. Their annual review should take place before each season and in many cases seasonal increases in prophylactic therapy will be required.

A serum sample for tryptase should be taken in all sudden, 
unexplained, anaphylactic or asthmatic deaths. None of our subjects with documented allergen exposure prior to death had a post-mortem serum measurement for tryptase. Tryptase is a useful marker of mast cell degranulation and can be taken up to 72 hours after death. ${ }^{32-34}$

\section{Conclusions}

In this case series of paediatric asthma deaths, a number of important risk factors have been identified. Psychosocial and behavioural factors can lead to poor-compliance with medication. The use of non-combination LABA inhalers contributes to confusion with treatment and underuse of ICS particularly without a written management plan. Seasonal and allergic triggers remain unrecognised particularly in patients with less severe asthma as there is no routine allergy testing for asthma patients in the UK. The risks associated with disease severity and non-adherence with ICS are well recognised; however, these could be anticipated with the routine use of spirometry and a system for identifying those patients who use excessive SABAs or who fail to attend appointments. Many of the above risk factors are likely to be preventable if asthma is phenotyped, triggers identified early, and patients educated to self-manage their condition.

\section{Handling editor Maureen George}

Acknowledgements We wish to gratefully acknowledge the members of the Eastern Region asthma mortality and severe Morbidity Group who include: Dr Mohammed Azher, Dr Robert Bawden, Dr Seema Brij, Dr Rob.Buttery, Dr Melanie Clements, Dr Richard Dent, Dr David Evans, Dr K Ganeslingam, Professor Brian Harrison, Dr Tim Howes, Dr Richard lles, Dr Nick Innes, Dr Steve Jenkins, Dr She Lok, Dr Venkat Mahadevan, Ms Heather Matthews, Dr Dipak Mukherjee, Dr Douglas Newberry, Dr Anna Pawlowicz, Ms Linda Pearce, Dr K Pillai, Ms Jenny Pool, Dr Thomas Pulimood, Dr Crichton Ramsay, Dr Anthony Reed Dr Paul Singer, Dr John Stanger, Dr Paul Stephenson. Chair: Dr Shuaib Nasser.

Conflicts of interest The authors declare that they have no conflicts of interest in relation to this article.

Contributorship Dr Shuaib is the guarantor, Professor Brian Harrison chaired the committee 2001-2003, Dr Richard Isles was the principal paediatrician on the committee, Dr Katherine Anagnostou analysed the data and Dr Shuaib Nasser chaired the committee 2003-6 and is the current chair.

Funding No funding was provided for this study.

\section{References}

1. Anderson HR, Gupta R, Strachan DP, Limb ES. 50 years of asthma: UK trends from 1955 to 2004. Thorax 2007;62(1):85-90. http://dx.doi.org/10.1136/thx.2006.066407

2. Ramyani Gupta and David Strachan. Asthma and allergic diseases (The health of children and young people. Chapter 7). Office for National Statistics, March 2004

3. Wareham NJ, Harrison BD, Jenkins PF, Nicholls J, Stableforth DE. A district confidential enquiry into deaths due to asthma. Thorax 1993;48(11):1117-20. http://dx.doi.org/10.1136/thx.48.11.1117

4. Mohan G, Harrison BD, Badminton RM, Mildenhall S, Wareham NJ. A confidential enquiry into deaths caused by asthma in an English health region: implications for general practice. Br J Gen Pract 1996;46(410):529-32.

5. Harrison B, Stephenson P, Mohan G, Nasser S. An ongoing Confidential Enquiry into asthma deaths in the Eastern Region of the UK, 2001-2003. Prim Care Respir J 2005; 14(6):303-13. http://dx.doi.org/10.1016/j.pcri.2005.08.004

6. Strunk RC, Mrazek DA. Deaths from asthma in childhood: can they be predicted? N Engl Reg Allergy Proc 1986;7(5):454-61. http://dx.doi.org/10.2500/108854186778984691

7. Friedman MS. Psychological factors associated with pediatric asthma death: a review. J Asthma 1984;21(2):97-117. http://dx.doi.org/10.3109/02770908409077408
8. Fletcher HJ, Ibrahim SA, Speight N. Survey of asthma deaths in the Northern region, 1970-85. Arch Dis Child 1990;65(2):163-7. http://dx.doi.org/10.1136/adc.65.2.163

9. Jørgensen IM, Jensen VB, Bülow S, Dahm TL, Prahl P, Juel K. Asthma mortality in the Danish child population:risk factors and causes of asthma death. Pediatr Pulmonol 2003;36(2):142-7. http://dx.doi.org/10.1002/ppul.10305

10. Miller BD, Strunk RC. Circumstances surrounding the deaths of children due to asthma. A case-control study. Am J Dis Child 1989;143(11):1294-9.

11. Bergström SE, Boman $G$, Eriksson L, et al. Asthma mortality among Swedish children and young adults, a 10-year study. Respir Med 2008;102(9):1335-41. Epub 2008 Jul 17

12. Rea $H H$, Sears MR, Beaglehole R, et al. Lessons from the national asthma mortality study: circumstances surrounding death. N Z Med J 1987;100(816):10-13.

13. Fregonese $L$, Silvestri $M$, Sabatini F, Defilippi AC, Rossi GA. Severe and near-fatal asthma in children and adolescents. Monaldi Arch Chest Dis 2001;56(5):423-8.

14. Evans S, Streather M, Walford H. Eastern Region Public Health Observatory (erpho). October 2005, Issue 14.

15. British Guideline on the Management of Asthma. A national clinical guideline. Thorax 2008;63(Suppl IV):iv1-iv121. http://dx.doi.org/10.1136/thx.2008.097741

16. Department of Communities and Local Government, Indices of Deprivation 2007

17. Robertson CF, Rubinfeld AR,Bowes G. Pediatric asthma deaths in Victoria: The mild are at risk. Pediatr Pulmonol 1992;13(2):95-100. http://dx.doi.org/10.1002/ppul.1950130207

18. Enright PL, Lebowitz MD, Cockroft DW. Physiologic measures: pulmonary function tests. Asthma outcome. Am J Respir Crit Care Med 1994;149(2 Pt 2):S9-18: discussion S19-20

19. Ramsey CD, Celedon JC, Sredl DL, Weiss ST, Cloutier MM. Predictors of disease severity in children with asthma in Hartford, Connecticut. Pediatr Pulmonol 2005;39:268-75. http://dx.doi.org/10.1002/ppul.20177

20. Loeb JS, Blower WC, Feldstein JF, Koch BA, Munlin AL, Hardie WD. Acceptability and repeatability of spirometry in children using updated ATS/ERS criteria. Pediatr Pulmonol 2008;43:1020-24. http://dx.doi.org/10.1002/ppul.20908

21. Ducharme FM, Bhogal SK. The role of written action plans in childhood asthma. Curr Opin Allergy Clin Immunol 2008;8(2):177-88. http://dx.doi.org/10.1097/ACI.0b013e3282f7cd58

22. Zemek RL, Bhogal SK, Ducharme FM. Systematic review of randomized controlled trials examining written action plans in children: what is the plan? Arch Pediatr Adolesc Med 2008;162(2):157-63. http://dx.doi.org/10.1001/archpediatrics.2007.34

23. Larsen GL. Asthma in children. N Engl J Med 1992;326(23):1540-5. http://dx.doi.org/10.1056/NEJM199206043262306

24. Salpeter SR, Buckley NS, Ormiston TM, Salpeter EE. Meta-analysis: effect of longacting beta-agonists on severe asthma exacerbations and asthma-related deaths. Ann Intern Med 2006;144(12):904-12.

25. Walters EH, Gibson PG, Lasserson TJ, Walters JA. Long-acting beta2-agonists for chronic asthma in adults and children where background therapy contains varied or no inhaled corticosteroid. Cochrane Database Syst Rev 2007 Jan 24;(1):CD001385

26. Thomson NC, Chaudhuri R. Asthma in smokers: challenges and opportunities. Curr Opin Pulm Med 2009;15(1):39-45. http://dx.doi.org/10.1097/ MCP.0b013e32831da894

27. Thomson NC, Spears M. The influence of smoking on the treatment response in patients with asthma. Curr Opin Allergy Clin Immunol 2005;5(1):57-63. http://dx.doi.org/10.1097/00130832-200502000-00011

28. Thomson NC, Chaudhuri R, Livingston E. Asthma and cigarette smoking. Eur Respir J 2004;24(5):822-33. http://dx.doi.org/10.1183/09031936.04.00039004

29. Soussan D, Liard R, Zureik M, Touron D, Rogeaux Y, Neukirch F. Treatment adherence, passive smoking, and asthma control: a three year cohort study. Arch Dis Child 2003;88(3):229-33. http://dx.doi.org/10.1136/adc.88.3.229

30. Vogel NM, Katz HT, Lopez R, Lang DM. Food allergy is associated with potentially fatal childhood asthma. J Asthma 2008;45(10):862-6. http://dx.doi.org/10.1080/02770900802444195

31. Nasser SM, Pulimood TB. Allergens and Thunderstorm Asthma. Current Allergy and Asthma Reports 2009;9:384-90. http://dx.doi.org/10.1007/s11882-009-0056-8

32. Schwartz LB. Diagnostic value of tryptase in anaphylaxis and mastocytosis. Immunol Allergy Clin North Am 2006;26(3):451-63. http://dx.doi.org/10.1016/j.iac.2006.05.010

33. Schwartz LB, Metcalfe DD, Miller JS, Earl H, Sullivan T. Tryptase levels as an indicator of mast-cell activation in systemic anaphylaxis and mastocytosis. N Eng/ J Med 1987;316(26):1622-6. http://dx.doi.org/10.1056/NEJM198706253162603

34. Hogan AD, Schwartz LB. Markers of mast cell degranulation. Methods 1997;13(1):43-52. http://dx.doi.org/10.1006/meth.1997.0494 